\title{
Cd Subcellular Localization in Root Tips of Hordeum vulgare
}

\author{
Qiuyue Shi ${ }^{1}$, Junran Wang ${ }^{1}$ Jinhua Zou ${ }^{1}$, Ze Jiang², Jiayue Wang', \\ Hangfeng Wu ${ }^{1}$, Wusheng Jiang ${ }^{1}$, Donghua Liu ${ }^{*}$
}

\author{
${ }^{1}$ Tianjin Key Laboratory of Animal and Plant Resistance, College of Life Sciences, Tianjin Normal University, \\ Tianjin 300387, China \\ ${ }^{2}$ Tianjin Experimental High School, Tianjin 300074, China
}

Received: 19 November 2015

Accepted: 22 December 2015

\begin{abstract}
The effects of $\mathrm{Cd}$ on the subcellular localization in root tip cells of Hordeum vulgare were investigated by Energy dispersive x-ray analysis (EDXA) in order to further understand Cd toxic mechanisms in plants. EDXA showed that $\mathrm{Cd}$ ions were localized in meristem, elongation, and mature zone in the root tips. In transverse section of the mature zone, Cd was accumulated in epidermal, cortical, and vessel cells, and the level of $\mathrm{Cd}$ is in the order: epidermal cells $<$ vessel cells $<$ cortical cells. In cortical cells Cd ions were observed in cytoplasm and walls.
\end{abstract}

Keywords: Hordeum vulgare, cadmium (Cd), subcellular localization, root

\section{Introduction}

Naturally, cadmium $(\mathrm{Cd})$ is present in trace concentrations and is a widespread heavy metal released into the environment by natural sources, agriculture, and manifold industrial uses [1]. Cd accumulation in the environment now has a major environmental and human health problem [2]. Cd is a non-essential element for plant growth and can be dangerous for plants. Cd toxicity in plants is well documented, including inducement of low mitotic index and pycnosis, disturbance of mitosis [3-5], and inhibition of plant root and shoot growth [6-7].

$\mathrm{Cd}$ can be absorbed and accumulated in plant tissues where roots are the primary site of accumulation $[6,8]$. Plant roots are one of the organs most sensitive to environmental stress. After $\mathrm{Cd}$ is absorbed by roots, they can be deposited in different tissues. Knowledge about its deposition and distribution in tissue compartments can be gained through energy-dispersive x-ray analyses (EDXA). However, only a few investigations have been carried out using EDXA to localize intracellular Cd.

Higher plants such as Allium cepa, Vicia faba, Arabidopsis Thailand, and $H$. vulgare provide a useful genetic system for screening and monitoring environmental pollutants [9-11]. H. vulgare is well known as an excellent model plant and a useful biomarker for detecting heavy metal pollution in laboratories [11]. The aim of our study was to further understand $\mathrm{Cd}$ subcellular localization in root tip cells of $H$. vulgare under Cd stress by means of electron microscopy with EDXA. The data obtained here are useful for better understanding the mechanisms of Cdinduced cell toxicity.

*e-mail: donghua@mail.zlnet.com.cn 


\section{Methods}

\section{Culture Condition and Cadmium Treatment}

Healthy equally-sized seeds of $H$. vulgare were collected and soaked in distilled water for $24 \mathrm{~h}$ before starting the experiments. After the seeds were germinated in moistened gauze in the dark at $23^{\circ} \mathrm{C}$ for $12 \mathrm{~h}$, they were treated with $50 \mu \mathrm{M} \mathrm{Cd}$ for $48 \mathrm{~h}$. Cadmium chloride $\left(\mathrm{CdCl}_{2}\right)$ was used in the present investigation.

\section{Fluorescence Labelling of $\mathrm{Cd}$}

$H$. vulgare intact roots treated with or without $50 \mu \mathrm{M}$ $\mathrm{Cd}$ for $48 \mathrm{~h}$ were stained using the $\mathrm{Cd}$ - specific probe Leadmium TM Green AM solution (Molecular Probes, Life Technologies, California, USA) according to the manufacturer's instructions to visualize the Cd absorption and distribution. Roots were put into $20 \mathrm{mM} \mathrm{Na}_{2}$-EDTA for 15 min at room temperature, and then they were washed with the $\mathrm{ddH}_{2} \mathrm{O}$ three times $(3 \times 10 \mathrm{~min})$. A stock solution of $\mathrm{Cd}-$ specific probe was made by adding $50 \mu \mathrm{L}$ of dimethyl sulfoxide into a vial of the dye. This stock solution was then diluted 1:10 with $0.85 \% \mathrm{NaCl}$. The roots were immersed in the diluted stock solution at $37^{\circ} \mathrm{C}$ for $2 \mathrm{~h}$ in the dark, and then were washed with $0.85 \% \mathrm{NaCl}$ three times. Then the roots were stored in the dark at $4^{\circ} \mathrm{C}$ until fluorescence from the labeled $\mathrm{Cd}$ was visualized under a confocal laser scanning microscope (Nikon ECLIPSE 90i) using an exciter at $488 \mathrm{~nm}$ and a barrier at 590/50 nm.

\section{Sample Preparation for Scanning Electron Microscope}

Elemental distribution and composition of experimental plants was determined from samples of freeze-dried root materials. Ten root samples of $1 \mathrm{~cm}$

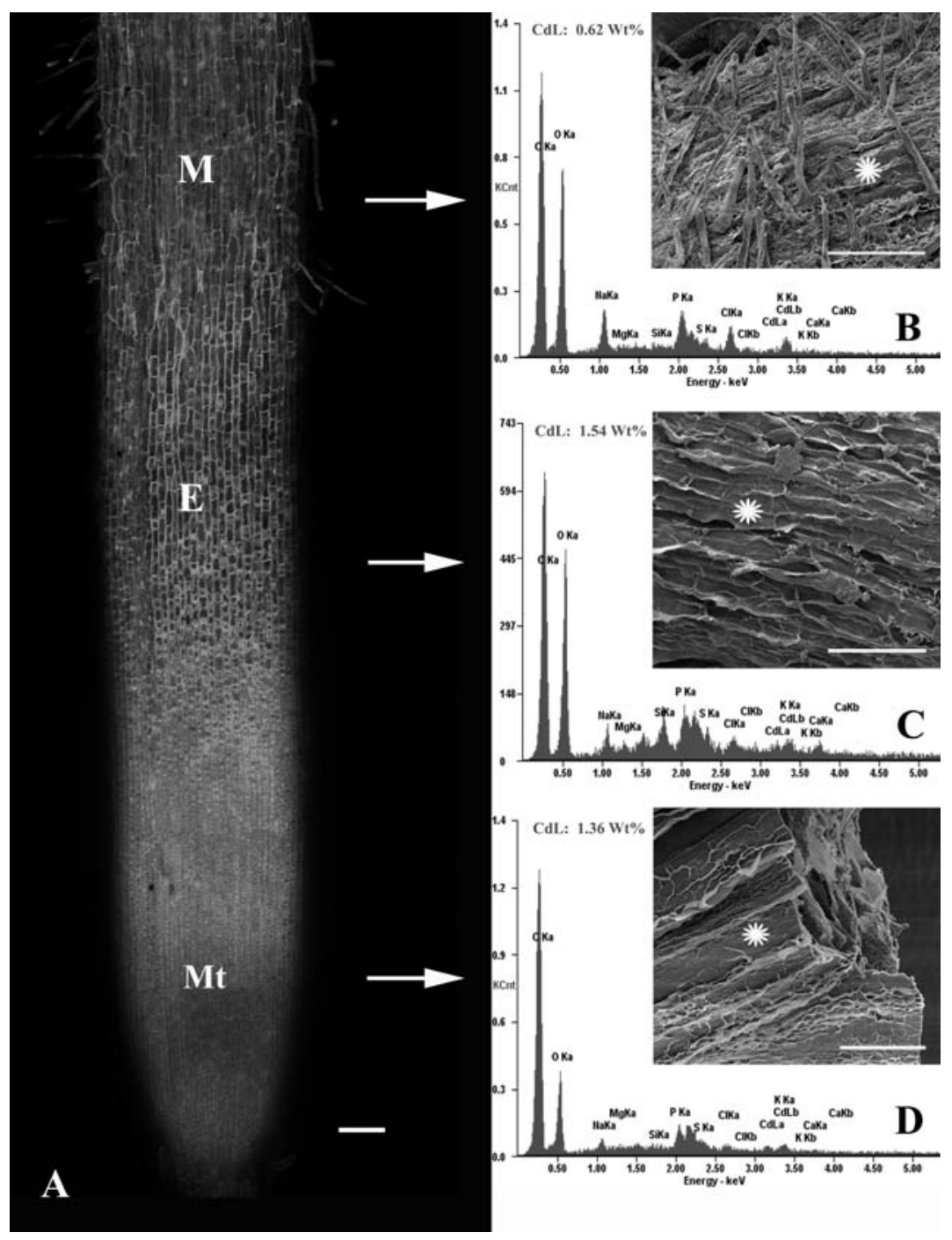

Fig. 1. EDXA spectra taken from the site of the SEM micrographs, showing Cd localization in different zones of root tip cells in H. vulgare exposed to $50 \mu \mathrm{M} \mathrm{Cd}$ for $48 \mathrm{~h}$ : A) Intact root. Image was taken at X4 magnification (Scale bar $=100 \mu \mathrm{m}$ ): B) Mature zone $($ Scale bar $=100 \mu \mathrm{m}):$ C) Elongation zone $($ Scale bar $=100 \mu \mathrm{m})$ : D) Meristm zone $($ Scale bar $=20 \mu \mathrm{m})$. Mt = meristem zone, $\mathrm{E}=$ elongation zone, $\mathrm{M}=$ mature zone. Scale bar $=100 \mu \mathrm{m}$. "*”site of the analysis; $\mathrm{x}$-axis - energy [keV]. 
length were cut from the root tips of $H$. vulgar, exposed to $50 \mu \mathrm{M} \mathrm{Cd}$ for $48 \mathrm{~h}$, and rapidly frozen in liquid nitrogen and lyophilized. Cross-sections of the roots (about $1 \mathrm{~mm}$ ) were coated by gold using a sputter/coater (EMITECH K550X, Quorum Group, England). The energy-dispersive $\mathrm{x}$-ray microanalytical studies were carried out using scanning electron microscopy (FEI Nova NANOSEM 230, Oregon, USA) provided with energy dispersive $\mathrm{X}$-ray spectrum analysis (EDXA) (Genesis Apollo 10, EDAX, USA). The spectra were collected at $20 \mathrm{KV}$ in an X-ray and X-ray detector equipped with a super ultra thin window. The collection time of spectra was 30-40s. The $\mathrm{Cd}$ content in the roots was shown by $\mathrm{wt} \%$ (weight percent), which means concentration percent on the basis of weight (or mass) of a particular element relative to total element weight (or mass).

\section{Results}

The results from EDXA showed subcellular localization of $\mathrm{Cd}$ on the surface of root tip cells in $H$. vulgare exposed to $50 \mu \mathrm{M} \mathrm{Cd}$ for $48 \mathrm{~h}$. The level of $\mathrm{Cd}$ in the different regions (meristem, elongation, and mature zone) was in the order: elongation zone $(1.54 \mathrm{Wt} \%)>$ meristem zone $(1.36 \mathrm{Wt} \%)>$ mature zone $(0.62 \mathrm{Wt} \%)$ (Fig. 1A-D). In the transverse section of the meristem the protoderm, ground merstem, and procambium can be distinguished in very close proximity to the apical meristem (Fig. 2A). The Cd content was in the order: procambium $(1.61 \mathrm{Wt} \%)$ $>$ protoderm $(1.33 \mathrm{Wt} \%)>$ ground meristem $(1.29 \mathrm{Wt} \%)$ (Fig. 2B-D). In transverse section of the mature zone, epidermis, cortex and vascular cylinder can be easily distinguished from each other (Fig. 3A). The level of $\mathrm{Cd}$ in epidermal cells $(0.54 \mathrm{Wt} \%)$ was low in comparison with cortical and vessel cells (Fig. 3B, E). In cortical cells more $\mathrm{Cd}$ ions were observed in the cytoplasm $(2.92 \mathrm{Wt} \%)$ than those in the cell walls (1.86 Wt\%) (Fig. 3C-D). In the vascular cylinder we observed that the $\mathrm{Cd}$ concentration in vessel walls $(2.7 \mathrm{Wt} \%)$ was high when compared with the adjacent parenchyma cells (1.67 Wt\%) (Fig. 3E-F). From a transverse section point of view, the $\mathrm{Cd}$ level in mature zone was high in comparison with the meristem zone.
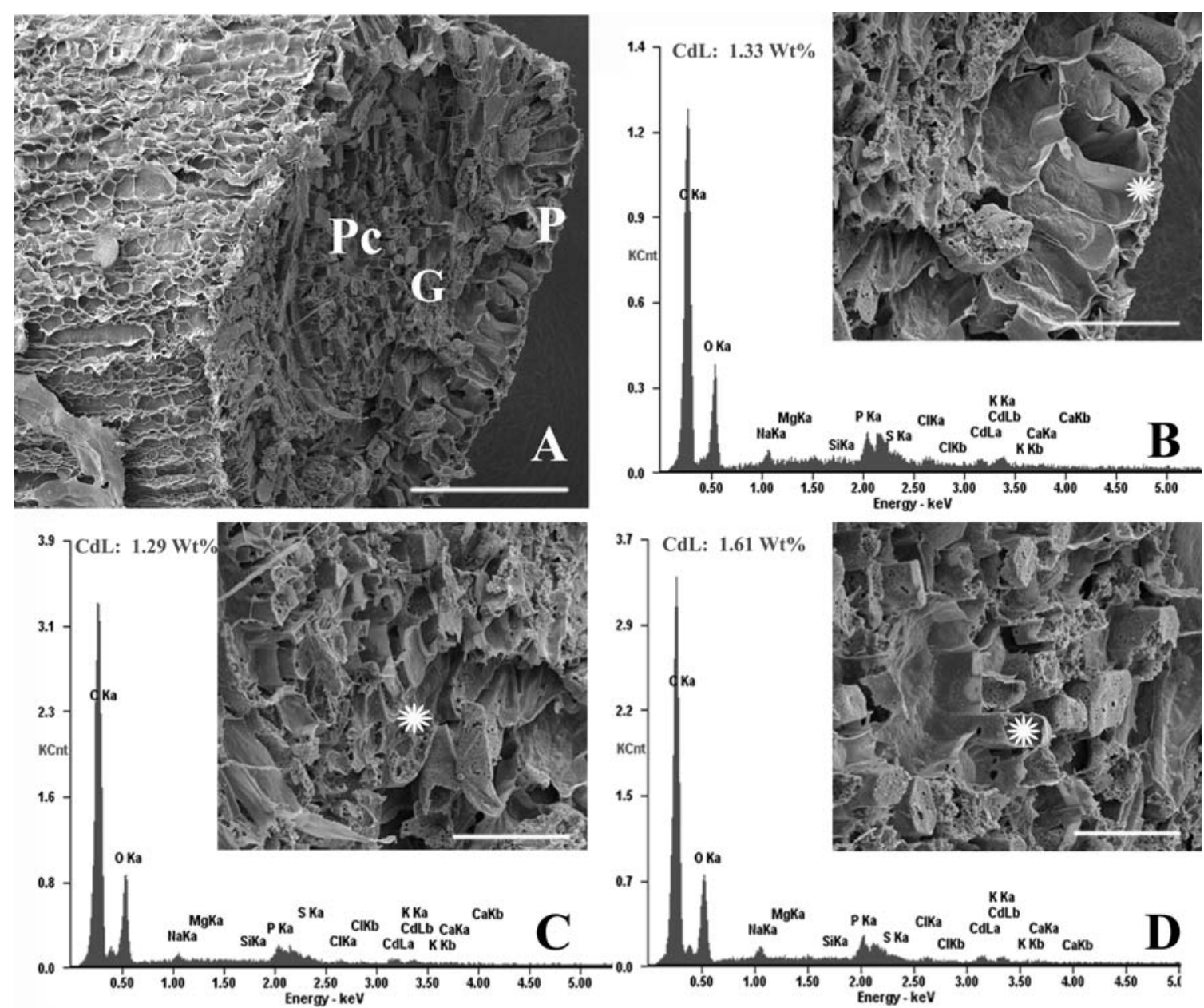

Fig. 2. EDXA spectra taken from the sites of the SEM micrographs, Cd localization in meristm zone in root tip cells of $H$. vulgare exposed to $50 \mu \mathrm{M} \mathrm{Cd}$ for $48 \mathrm{~h}$ : A) Transverse section of meristem zone (Scale bar $=100 \mu \mathrm{m})$ : B) Protoderm $(\mathrm{Scale}$ bar $=30 \mu \mathrm{m}): \mathrm{C}) \mathrm{Ground}$ meristem $($ Scale bar $=30 \mu \mathrm{m})$ : D) Procambium (Scale bar $=20 \mu \mathrm{m})$. “*”site of the analysis; $\mathrm{x}$-axis - energy $[\mathrm{keV}]$. $\mathrm{G}=$ ground meristem, $\mathrm{Pc}=$ procambium, $\mathrm{P}=$ protoderm. 


\section{Discussion}

The roots are the sole organ penetrating the soil, directly contacting with toxic metals. It is expected that they are the first to undergo toxicity and develop the responding symptoms. Therefore, evaluating the action mechanisms of $\mathrm{Cd}$ toxic to plant root tip cells and their consequences on $\mathrm{Cd}$ localization and genetic material, as performed in the present investigation, is very important.

EDXA as an analytical technique is very useful for analyzing localization of elements in biological specimens at the subcellular level. Cd ions were observed in elon-
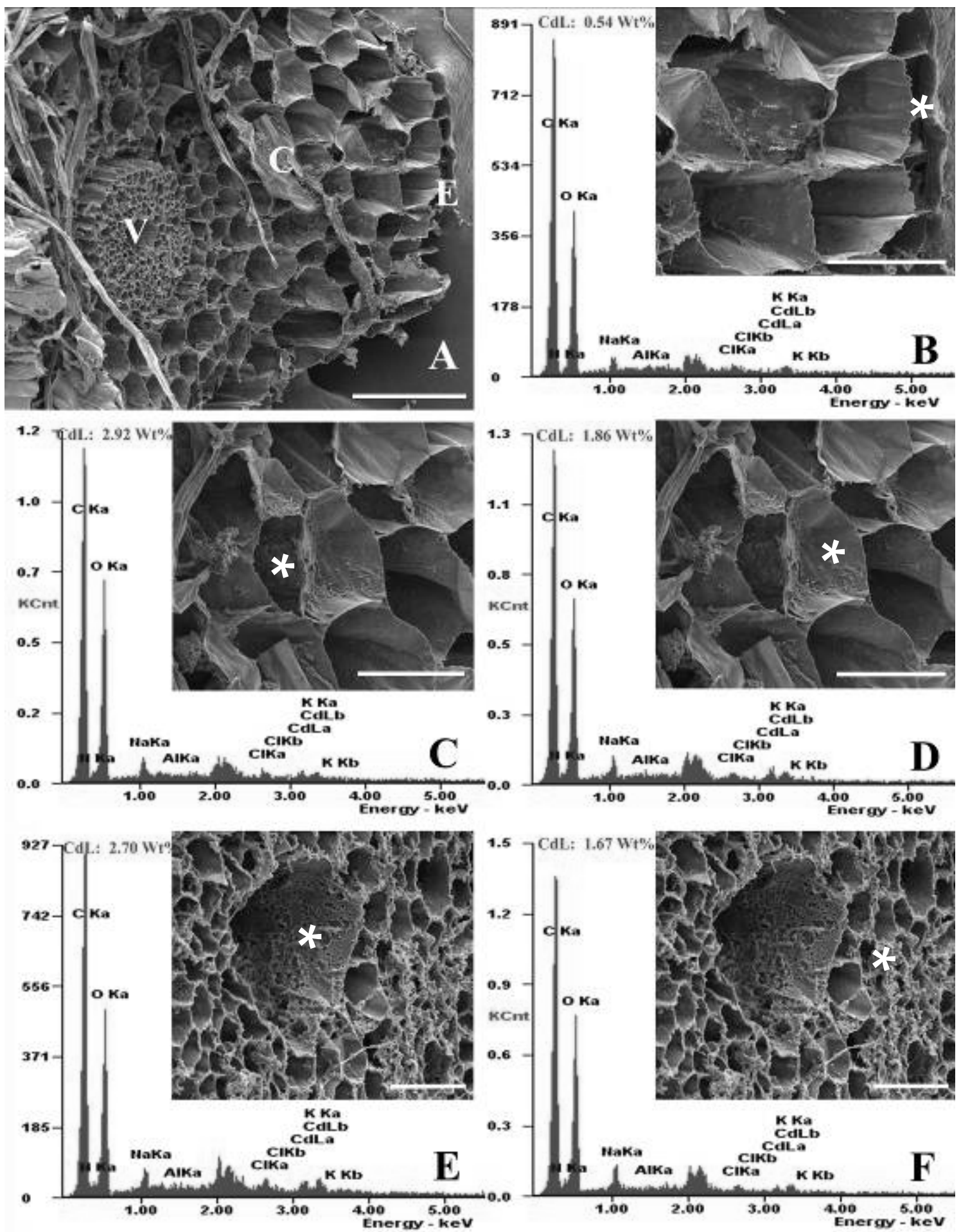

Fig. 3. EDXA spectra taken from the sites of the SEM micrographs, Cd localization in mature zone in root tip cells of $H$. vulgare exposed to $50 \mu \mathrm{M} \mathrm{Cd}$ for $48 \mathrm{~h}$ : A) Transverse section of mature zone (Scale bars $=100 \mu \mathrm{m})$ : B) Epidermal cells $($ Scale bar $=50 \mu \mathrm{m})$ : C $-\mathrm{D})$ Cortical cells: C) Cytoplasm: D) Cell wall (Scale bars $=50 \mu \mathrm{m})$ : E) Vessel cells $($ Scale bar $=20 \mu \mathrm{m}):$ F) Parenchyma cells $($ Scale bar $=20 \mu \mathrm{m})$. “*”site of the analysis; $\mathrm{x}$-axis - energy [keV]. C = cortex, $\mathrm{E}=$ epidermis, $\mathrm{V}=$ vascular cylinder. 
gation, meristem, and mature zone in root tips of $H$. vulgare exposed to $\mathrm{Cd}$ in the present investigation. From a transverse section point of view, the Cd level in the mature zone was high in comparison with the meristem zone due to its perfect conducting system. Root hairs of barley play an important role in the acquisition of $\mathrm{Cd}$ from soil. These results are consistent with those of Zheng et al. [12] and Balestri et al. [13], who observed that root hairs contribute significantly to Cd uptake in barley. Root hairs are found only in the maturation region of the root. They are outgrowths and have a large surface area, which makes absorbing both water and minerals more efficient using osmosis. The abundant channels and/or transporters in the plasma membrane of root hair cells can facilitate the uptake of $\mathrm{Cd}$. In addition, hairy roots can contribute to the hyperaccumulation of $\mathrm{Cd}$ in Noccaea (Thlaspi) caerulescens [14]. Thus, the higher root hair-mediated $\mathrm{Cd}$ influx may be a key contributor to the hyperaccumulation of $\mathrm{Cd}$ [15].

The results here revealed that the level of $\mathrm{Cd}$ in epidermal cells of the mature zone in root tips of $H$. vulgare exposed to Cd was low when compared with cortical and vessel cells. We suggest that $\mathrm{Cd}$ ions in the epidermal cells after $\mathrm{Cd}$ stress may be absorbed quickly by root hairs, then more $\mathrm{Cd}$ ions are accumulated in cortical cells. This result is in conflict with the findings of Seregin et al. [16]. More studies, however, are required in this direction.

The limited translocation of $\mathrm{Cd}$ from cortex into the vessel cells is believed to result from the barrier function of the root endodermis: its Casparian strips bar Cd entrance into the central cylinder [17]. The results from Seregin and Ivanov [15] showed that the insignificant metal translocation into the stele are probably related to the Casparian strip barrier in the endodermal cells, suggesting that predominant metal accumulated in all tissues of the root apex as the Casparian strips, and had not as yet developed in the dividing and elongating cells. At nonlethal concentrations $\mathrm{Cd}$ does not practically reach the stele because the Casparian strips were already formed in the root hair zone [16]. However, it is not known whether the Casparian strips are the only limiting factor restricting $\mathrm{Cd}$ transport across the endodermis into the central cylinder tissues. The results of this investigation indicated that $\mathrm{Cd}$ is bound to cell walls in root tips of barley, which is consistent with the findings of other workers, suggesting that cell walls are the main site of $\mathrm{Cd}$ accumulation [6, 18-20]. We suppose that once excessive $\mathrm{Cd}$ ions enter the cytoplasm, a defence mechanism becomes activated, protecting the cells against $\mathrm{Cd}$ toxicity. The root is the first plant tissue in direct contact with metal ions in the growth medium and plays a major role in metal tolerance [21]. Cd accumulation due to metal exclusion in the root should theoretically be the best strategy for defense against $\mathrm{Cd}$ toxicity. As the first barrier to prevent metals from entering a cell, the cell wall is a pivotal site for Cd storage in plants [22-23]. Recent findings have demonstrated that in order to enhance its heavymetal accumulation capacity the cell wall is even actively modified, which protects the protoplast. So metal-exposed plants can increase the amount of polysaccharides that bind heavy metal ions [24]. Santos et al. [25] found that Cd increased cell wall thickness in Gracilaria domingensis treated with 100,200 , and $300 \mu \mathrm{M}$ of Cd for $16 \mathrm{~d}$, suggesting that such an increase in cell wall thickness can be interpreted as a defense mechanism against exposure to $\mathrm{Cd}$ [26]. It is probable that the activity of Dictyosomes more intense in plants exposed to $\mathrm{Cd}$ and that this results in the large production of vehicles, which then format the matrix content of the cell wall [26]. Cytochemical evidence also confirms that cysteine-rich proteins, commonly referred to as phytochelatins, are localized in electron-dense granules in root cell walls of A. сера [27], which seems to contribute substantially to $\mathrm{Cd}$ detoxification.

In cortical cells more $\mathrm{Cd}$ ions were observed in the cytoplasm than those in the cell walls, suggesting that cytoplasm is one of the main storage sites of Cd in the root tip cells of $H$. vulgare, which supports the findings of Liu and Kottke [27], Liu et al. [20], and Ali et al. [28]. In the cytoplasm, vesicles arising from the endoplasmic reticulum and dictyosomes also contain Cd deposits. Usually, several vesicles are gradually fused together, producing a bigger cytoplasmic vacuole. The increased vacuolation in $\mathrm{Cd}-$ exposed cells can prevent the circulation of free $\mathrm{Cd}$ ions in the cytoplasm and forces them into a limited area [27, 29], which can reduce $\mathrm{Cd}$ toxicity. Cd remaining in the cytoplasm could be detoxified in the cytoplasm by high-affinity ligands, which is considered to be an important mechanism of heavy-metal detoxification and tolerance [30].

\section{Conclusions}

Based on the information provided in this article, it is concluded that 1) Meristem, elongation, and the mature zone are the main sites of Cd uptake and 2) Cytoplasm and walls are the main $\mathrm{Cd}$ storage sites.

\section{Acknowledgements}

This project was supported by the National Natural Science Foundation of China (grant No. 30972331). The authors wish to express their appreciation to the reviewers for this paper.

\section{References}

1. HARTWIG A. Mechanisms in cadmium-induced carcinogenicity: recent insights. Biometals 23, 951, 2010.

2. QIN R., JIANG W.S., LIU D.H. Cadmium can induce alterations in the cellular localization and expression of three major nucleolar proteins in root tip cells of Vicia faba L. Plant Soil 368, 365, 2013.

3. XU P., LIU D., JIANG W. Cadmium effects on the organization of microtubular cytoskeleton in interphase and mitotic cells of Allium sativum. Biol. Plantarum 53, 387, 2009.

4. ZHANG S.S., ZHANG H.M., QIN R., JIANG W.S., LIU D.H. Cadmium induction of lipid peroxidation and effects on root tip cells and antioxidant enzyme activities in Vicia faba L. Ecotoxicology 18, 814, 2009. 
5. SHI H.P., FENG Y., WANG Y.L., TSANG P.K.E. Effect of cadmium on cytogenetic toxicity in hairy roots of Wedelia trilobata $\mathrm{L}$. and their alleviation by exogenous $\mathrm{CaCl}_{2}$. Environ. Sci. Poll. Res. 21, 1436, 2014.

6. GE W., JIAO Y.Q., SUN B.L., QIN R., JIANG W.S., LIU D.H. Cadmium-mediated oxidative stress and ultrastructural changes in root cells of poplar cultivars. S. Afr. J. Bot. 83, 98, 2012.

7. JIAO Y.Q., GE W., QIN R., SUN B.L., JIANG W.S., LIU D.H. Influence of cadmium stress on growth, ultrastructure and antioxidative enzymes in Populus 2025. Fresen. Environ. Bul,. 2 , 137., 2012.

8. VITÓRIA A.P., LEA P.J., AZEVEDO R.A. Antioxidant enzymes responses to cadmium in radish tissues. Phytochemtry 57, 701, 2001.

9. FISKESJÖ G. The Allium test as a standard in environmental monitoring. Hereditas 102, 99, 1985.

10. LIU D.H., JIANG W.S., WANG W., ZHAI L. Evaluation of metal ion toxicity on root tip cells by the Allium test. Isr. J. Plant Sci. 43, 125, 1995.

11. LIMAN R., AKYIL D.K., EREN Y., KONUK M. Testing of the mutagenicity and genotoxicity of metolcarb by using both Ames/Salmonella and Allium test. Chemosphere 80, 1056, 2010.

12. ZHENG R.L., LI H.F., JIANG R.F., RÖMHELD V., ZHANG F.S., ZHAO F.J. The role of root hairs in cadmium acquisition by barley. Environ. Poll. 159, 408, 2011.

13. BALESTRI M., CECCARINI A., FORINO L.M.C., ZELKO I., MARTINKA M., LUX A., CASTIGLIONE M.R. Cadmium uptake, localization and stress induced morphogenic response in the fern Pteris vittata. Planta 239, 1055, 2014.

14. NEDELKOSKA T.M., DORAN P.M. Hyperaccumulation of cadmium by hairy roots of Thlaspi caerulescens. Biotech. Bioeng. 67, 607, 2000.

15. SUN J., WANG R.G., LIU Z.Q., DING Y.Z., LI T.Q. Noninvasive microelectrode cadmium flux measurements reveal the spatial characteristics and real-time kinetics of cadmium transport in hyperaccumulator and nonhyperaccumulator ecotypes of Sedum alfredii. J. Plant Physiol. 170, 355, 2013.

16. SEREGIN I.V., SHPIGUN L.K., IVANOV V.B. Distribution and toxic effects of cadmium and lead on Maize roots. Rus. J. Plant Physiol. 51, 525, 2004.

17. SEREGIN I.V., IVANOV V.B. Histochemical investigation of cadmium and lead distribution in plants, Fiziol. Rast. (Moscow). Russ. J. Plant Physiol. 44, 915, 1997.

18. KHAN D.H., DUCKETT J.G., FRANKLAND B., KIRKHAM B. An X-ray microanalytical study of the distri- bution of cadmium in roots of Zea mays L. J. Plant Physiol 115, 19, 1984

19. VÁZQUEZ M.D., BARCELÓ J., POSCHENRIEDER C., MÁCICO J., HATTON P., BAKER A.J.M., COPE G.H. Localization of zinc and cadmium in Thlaspi caerulescens (Brassicaceae), a metallophyte that can hyperaccumulate both metals. J. Plant Physiol. 140, 350, 1992.

20. LIU D.H., KOTTKE I., ADAM D. Localization of cadmium in the root cells of Allium cepa by energy dispersive X-ray analysis. Biol. Plant. 51, 363, 2007.

21. ZHU X.F., LEI G.J., JIANG T., LIU Y., LI G.X., ZHENG S.J. Cell wall polysaccharides are involved in P-deficiencyinduced Cd exclusion in Arabidopsis thaliana. Planta 236, 989, 2012

22. LOZANO-RODRÍGUEZ E., HERNÁNDEZ L.E., BONAY P., CARPENA R.O. Distribution of Cd in shoot and root tissues of maize and pea plants: physiological disturbances. J. Experi. Bot. 48, 123, 1997.

23. CARRIER P., BARYLA A., HAVAUX M. Cadmium distribution and microlocalization in oilseed rape (Brassica napus) after long term growth on cadmium-contaminated soil. Planta 216, 939, 2003.

24. KRZESZOWSKA M. The cell wall in plant cell response to trace metals: polysaccharide remodeling and its role in defense strategy. Acta Physiol. Plantarum 33, 35, 2010.

25. SANTOS R.W., SCHMIDT E.C., BOUZON Z.L. Changes in ultrastructure and cytochemistry of the agarophyte Gracilaria domingensis (Rhodophyta, Gracilariales) treated with cadmium. Protoplasma 250, 297, 2013.

26. BOUZON Z.L., FERREIRA E.C., SANTOS R., SCHERNER F., HORTA PAULO A., MARASCHIN M., SCHMIDT E.C. Influences of cadmium on fine structure and metabolism of Hypnea musciformis (Rhodophyta, Gigartinales) cultivated in vitro. Protoplasma 249, 637, 2012.

27. LIU D.H., KOTTKE I. Subcellular localization of cadmium in the root cells of Allium cepa by electron energy loss spectroscopy and cytochemistry. J. Biosci. 29, 329, 2004.

28. ALI B., QIAN P., JIN R., ALI S., KHAN M., AZIZ R., TIAN T., ZHOU W. Physiological and ultra-structural changes in Brassica napus seedlings induced by cadmium stress. Biol. Plantarum 58, 131, 2014

29. JIANG W.S., LIU D.H., XU P. Cd-induced system of defence in the garlic root meristematic cells. Biol. Plantarum 53, 369, 2009.

30. HALL J.L. Cellular mechanisms for heavy metal detoxification and tolerance. J. Experi. Bot. 53, 1, 2002. 